\title{
Research
}

Paper

\section{In vivo chromosome damaging effects of an inosine monophosphate dehydrogenase inhibitor: Ribavirin in mice}

\author{
K. P. Seetharama Rao, K. Narayana*
}

\begin{abstract}
Department of Anatomy, Faculty of Medicine, University Putra Malaysia, 43400 UPM Serdang,

Selangor, Malaysia. *Department of Anatomy, Centre for Basic Sciences, Kasturba Medical College, Bejai, Mangalore-575004, Karnataka, India.
\end{abstract}

Received: 21.5.2004

Revised: 6.10.2004

Accepted: 10.10.2004

Correspondence to: $\mathrm{K}$. Narayana

E-mail:

narayana68@yahoo.com

\begin{abstract}
ABSTACT
Objective: To investigate the in vivo mutagenic effects of ribavirin in mice. Methods: Mice were injected (i.p.) 20, 100, or $200 \mathrm{mg} / \mathrm{kg}$ ribavirin (single exposure) for bone marrow micronucleus, peripheral blood micronucleus and bone marrow chromosome aberration tests. Five treatments of $200 \mathrm{mg} / \mathrm{kg}$ ribavirin was given (i.p.) for sperm morphology test. The tests were performed as per the standard procedures.

Results: Ribavirin induced significant number of micronucleated polychromatic erythrocytes (MNPCEs) at 24, 48 and $72 \mathrm{~h}$ following the exposure with more effects at $24 \mathrm{~h}(\mathrm{p}<0.05-0.001)$. Micronucleated PCEs were more at $48 \mathrm{~h}$ in lower dose-levels and at $72 \mathrm{~h}$ in highest dose-level in the peripheral blood $(p<0.05-0.001)$. Ribavirin induced structural chromosomal damage hence producing the fragments for the micronucleus formation. Ribavirin decreased the $\mathrm{PCE} \%, \mathrm{P} / \mathrm{N}$ ratio and the mitotic index indicating that it prevents cell division in mouse bone marrow. Ribavirin also decreased the testis weight and induced the formation of abnormal sperms.

Conclusion: Ribavirin is a potent mutagen and cytotoxic agent in mice in vivo. Further, it also induces point mutations in germ cells yielding abnormal sperms. The genotoxic effects of ribavirin are not exerted in a dose-dependent pattern in mouse.
\end{abstract}

KEY WORDS: Acentrics, bone marrow, genotoxicity, mutagenesis

\section{Introduction}

Ribavirin (Tribavirin) is a synthetic nucleoside analog used in the treatment of various viral infections. ${ }^{[1]}$ It inhibits viral replication via a variety of mechanisms; however, its antiviral properties appear to be by inhibition of the cellular inosine 5, monophosphate dehydrogenase activity that consequently depletes the intracellular GTP pool. ${ }^{[2]}$ Ribavirin treatment induces reversible anemia, ${ }^{|3|}$ and other hematological disorders. ${ }^{[4-6]}$ Although there are no comparable data for humans, ${ }^{[2]}$ ribavirin is a teratogen in all animals tested affecting the limb developments, eye formation and development of the central nervous system. ${ }^{\text {[7-10] }}$

Ribavirin increased the incidence of mutations in vitro in mouse Balb/c3T3 (fibroblasts), and lymphoma cells, although its carcinogenic potential is not yet clear. ${ }^{[1]]}$ It induced the formation of micronuclei in mouse bone marrow erythrocytes at the dose-levels of 20,100 or $200 \mathrm{mg} / \mathrm{kg}$, and chromosomal damages at $200 \mathrm{mg} / \mathrm{kg}$ after 2-5 exposures, ${ }^{[12]}$ and following a single acute exposure of very high doses. ${ }^{[13]}$ Ribavirin was found to be non-mutagenic in rats when investigated by dominant lethal test, although the results were not unequivocal. ${ }^{[14]}$
However, it induced the generation of a significant number of abnormal spermatozoa ${ }^{[15]}$ and decreased the sperm counts ${ }^{[16]}$ with some relation to the doses and sampling points tested in rats. In rat bone marrow cells, a single exposure of 10-200 $\mathrm{mg} / \mathrm{kg}$ ribavirin induced the formation of micronuclei except at $10 \mathrm{mg} / \mathrm{kg}$, almost in a dose-dependent pattern but without any well-defined sex-differences. ${ }^{[17]}$ Even though its mutagenicity has been reported based on the results of bone marrow micronucleus test and sperm morphology test in the rat, the results of in vitro ${ }^{[18]}$ studies revealed otherwise. Besides, the previous studies in mice have employed multiple treatments ${ }^{[12]}$ or the exposure of very high doses ${ }^{[13]}$ and the toxicity was evaluated by the micronucleus test. To establish the mutagenicity of any chemical, the chromosome-damaging effects should be evaluated by multiple tests. Although a few reports exist on the toxic effects of ribavirin, there is still a controversy regarding whether or not ribavirin induces any chromosomal damage. Moreover, the micronucleus or sperm morphology tests have limitations as they are unable to identify the type of chromosomal damage induced. Hence, the present study was planned to investigate the genotoxicity of ribavirin in mice in vivo. 


\section{Materials and Methods}

\section{Animals}

Swiss albino inbred mice (Mus musculus; 8-10 weeks old; 26-30 g, body weight) were housed in plastic cages with paddy husk bedding. Animal house temperature was maintained at $28 \pm 1{ }^{\circ} \mathrm{C}$. Animals were given food and water ad libitum. Mice were segregated into groups of 5 each. All experiments were conducted as per the guidelines of the institutional ethical committee and those of Government of India. In all experiments, the animals were anesthetized (Pentabarbitone sodium $45 \mathrm{mg} / \mathrm{kg}$, i. p.) and then sacrificed by overdose of the same.

\section{Chemicals}

Ribavirin (Virazole; ICN pharmaceuticals, Inc., CA; Lot No. 94J02) was dissolved in water just before use and injected intraperitoneally. The dose selection was based on the previous studies. ${ }^{[12,16]}$ Briefly, $20 \mathrm{mg} / \mathrm{kg}$ is an antiviral dose, whereas the other two are the higher doses. The basis for their selection was that they were used in earlier studies which revealed the controversial results.

\section{Bone marrow micronucleus assay}

One group which received water served as control. Three groups were treated with $20 \mathrm{mg} / \mathrm{kg}$, another 3 groups with $100 \mathrm{mg} / \mathrm{kg}$ and remaining 3 groups with $200 \mathrm{mg} / \mathrm{kg}$. From the ribavirin-treated category one group each from different doselevels was selected either at 24,48 or $72 \mathrm{~h}$ (the same animals were used for peripheral blood micronucleus test and chromosome aberration test; vide infra). The animals were anesthetized and the bone marrow was aspirated from femurs into $1 \mathrm{ml}$ of $5 \%$ bovine albumin in phosphate buffered saline (pH 7.2) as previously described. ${ }^{[12,17,19]}$ The cell suspension was centrifuged (1000 rpm for $5 \mathrm{~min}$ ) and the smears were prepared from the pellet on chemically cleaned glass slides and stained with May-Gruenwald-Giemsa. ${ }^{[12]}$ The smears were analyzed under the oil immersion objective and 2000 polychromatic erythrocytes/animal were counted. Concurrently encountered normochromatic erythrocytes (NCEs), micronucleated PCEs (MNPCEs) and MNNCEs were also counted.

\section{Peripheral blood micronucleus assay}

This test was performed to investigate the mutagenicity in circulating erythrocytes. If this test is conducted along with bone marrow micronucleus test and chromosome aberration test, the accuracy of genotoxicity evaluation is $100 \%$. This assay was conducted following a single exposure to ribavirin 20, 100 or $200 \mathrm{mg} / \mathrm{kg}$ at $0,24,48$ or $72 \mathrm{~h}$ in the same animals used for bone marrow micronucleus assay (5 animals/group/sample time). The blood was collected from the ventral tail vein and the blood sample before treatment served as control. The smears were prepared on clean glass slides and stained with the May-Gruenwald-Giemsa.

Two thousand PCEs were scored and concurrently met MNPCEs were recorded and expressed as percentage incidence. Another 100 PCEs were separately recorded and simultaneously met NCEs were counted to express NCE\% and
MNNCE\%. Number of PCEs scored was reduced when it was not possible to score 100 PCEs in cases of severe inhibition of erythropoeisis.

\section{Bone marrow mitotic chromosome analysis}

This test was also conducted in the same animals used for the micronucleus tests. Single treatment of 20, 100 or 200 $\mathrm{mg} / \mathrm{kg}$ of ribavirin was given (5 animals/sample time/dose) to study the time- and dose-responses. The sampling was done at 48 and $72 \mathrm{~h}$ for 20 and $100 \mathrm{mg} / \mathrm{kg}$ and at 24,48 or $72 \mathrm{~h}$ for $200 \mathrm{mg} / \mathrm{kg}$. The procedure of the chromosome preparation adopted was that of Adler ${ }^{[20]}$ and Savage. ${ }^{[21]}$ Briefly, $0.2 \mathrm{ml}$ of $0.02 \%$ colchicine (Sigma Chemicals) was injected intraperitoneally to arrest the cell division and after $2 \mathrm{~h}$ the animals were sacrificed by the lethal dose of anesthesia. The marrow was aspirated from the femurs into a syringe containing $0.075 \mathrm{KCl}(560 \mathrm{mg} / 100 \mathrm{ml}$ distilled water). The marrow suspension was incubated at $37^{\circ} \mathrm{C}$ for $15-20 \mathrm{~min}$ and centrifuged at $1000 \mathrm{rpm}$ for $10 \mathrm{~min}$. The supernatant was discarded. The pellet was mixed with the fixative $(3: 1$, methanol: acetic acid) and the suspension was allowed to stand for $30 \mathrm{~min}$ and then centrifuged. The preparation was given two changes of fixative. The pellet was mixed thoroughly in 1 $\mathrm{ml}$ of fresh fixative and 2-3 drops of the suspension was placed on a clean glass slide from a height. The slides were flamedried and stained with 10\% Giemsa at pH 6.8 for $15-20$ min. Slides were screened for chromosome abnormalities as per the standard method. ${ }^{[20,21]}$

\section{Sperm morphology assay}

One group of mice was treated (i.p.) with ribavirin 200 $\mathrm{mg} / \mathrm{kg} /$ day for 5 consecutive days at intervals of $24 \mathrm{~h}$. Another group of mice, which received water served as control (5 animals/group). All animals were sacrificed on Day 35 following the last exposure. Laparotomy was conducted and the reproductive tract was exposed. The testes and the epididymes were removed. The tunica albugenia was removed and the testes were weighed (paired weight). The epididymis was minced in $1 \mathrm{ml}$ phosphate buffered saline into a suspension and filtered through a nylon cloth. To the filtrate, 1 drop of eosin Y was added and smears were prepared. Two thousand spermatozoa/rat were examined for shape abnormalities as per the standard procedure, ${ }^{[22,23]}$ and expressed as percentage incidence of abnormal sperms.

\section{Statistical analysis}

Data were expressed as mean+SEM for each group and subjected to the statistical analysis by ANOVA (one-way) and Bonferroni post hoc test. $\mathrm{P}<0.05$ was considered as the level of significance.

\section{Results}

\section{Bone marrow micronucleus assay}

All three doses of ribavirin induced the formation of MNPCEs ( $\mathrm{P}<0.05-0.001$; Figure 1a) following a single exposure except at $72 \mathrm{~h}$ in $20 \mathrm{mg} / \mathrm{kg}$. At 24 and $48 \mathrm{~h}$, there were no differences in MNPCE\% at 20 and $100 \mathrm{mg} / \mathrm{kg}$ but the effects of $200 \mathrm{mg} / \mathrm{kg}$ significantly differed from that of the other two doses. The two higher doses significantly increased the 
MNPCE\% at $72 \mathrm{~h}$, but $20 \mathrm{mg} / \mathrm{kg}$ dose did not. The PCE\% was decreased at the two higher dose-levels at 24 and $48 \mathrm{~h}$, and also at $72 \mathrm{~h}$ in $200 \mathrm{mg} / \mathrm{kg}$ and similar was the case with the P/ $\mathrm{N}$ ratio (Table 1). Micronucleated NCEs (Figure 1b) did not respond significantly to the toxicity of the drug.

\section{Peripheral blood micronucleus assay}

At $24 \mathrm{~h}$, a significant elevation in MNPCEs (Figure 1c) was observed in $20 \mathrm{mg} / \mathrm{kg}$ group, but not in the other two treated groups. At $48 \mathrm{~h}$, there was a dose-dependent increase in MNPCE\% with more than two-fold increase over the $20 \mathrm{mg} / \mathrm{kg}$ group and similar was the case at $72 \mathrm{~h}$. At 24 and $72 \mathrm{~h}$, MNNCE\% (Figure 1d) did not show any significant increase, but at $48 \mathrm{~h}$, it was significant in the 20 and $100 \mathrm{mg} / \mathrm{kg}$ groups. The two cytotoxic parameters (PCE\% and $\mathrm{P} / \mathrm{N}$ ) did not show any change at $20 \mathrm{mg} / \mathrm{kg}$, but at $100 \mathrm{mg} / \mathrm{kg}$, and as time advanced the cytotoxicity also increased. The higher dose, 200 $\mathrm{mg} / \mathrm{kg}$ also showed cytotoxicity, however, the $100 \mathrm{mg} / \mathrm{kg}$ dosegroup was the most affected (Table 2).

\section{Table 1}

\section{Bone marrow micronucleus test in ribavirin treated mice}

\begin{tabular}{|c|c|c|c|c|c|}
\hline Drug (mg/kg) & Sample time (h) & MNPCE\% & MNNCE\% & PCE\% & $P / N$ \\
\hline \multirow[t]{2}{*}{0} & 0 & $0.18 \pm 0.04$ & $0.21 \pm 0.06$ & $56.67 \pm 2.92$ & $1.34 \pm 0.15$ \\
\hline & 24 & $0.72 \pm 0.09^{\star \star *}$ & ND & $62.34 \pm 7.49$ & $1.94 \pm 0.47$ \\
\hline \multirow[t]{3}{*}{20} & 48 & $0.48 \pm 0.01^{* *}$ & $0.13 \pm 0.01$ & $56.74 \pm 2.30$ & $1.33 \pm 0.13$ \\
\hline & 72 & $0.25 \pm 0.04$ & $0.11 \pm 0.04$ & $61.36 \pm 0.49$ & $1.59 \pm 0.03$ \\
\hline & 24 & $0.73 \pm 0.14^{\star \star}$ & $0.09 \pm 0.02$ & $40.68 \pm 3.59^{\star *}$ & $0.70 \pm 0.10^{\star *}$ \\
\hline 100 & 48 & $0.47 \pm 0.09^{\star \star}$ & $0.26 \pm 0.05$ & $36.94 \pm 4.77^{\star \star}$ & $0.66 \pm 0.16^{\star *}$ \\
\hline \multirow[t]{2}{*}{200} & 48 & $0.55 \pm 0.08^{* \star}$ & $0.18 \pm 0.02$ & $14.12 \pm 2.12^{\star \star \star}$ & $0.17 \pm 0.03^{\star * \star}$ \\
\hline & 72 & $0.92 \pm 0.16^{\star * *}$ & $0.40 \pm 0.18$ & $39.05 \pm 8.83^{\star *}$ & $0.77 \pm 0.31^{* *}$ \\
\hline
\end{tabular}

Values are mean \pm SEM from 5 animals/group. Bone marrow was collected from 2 rats at $24 \mathrm{~h}, 2$ rats at $48 \mathrm{~h}$ and 1 rat at $72 \mathrm{~h}$ in control group. ${ }^{*} \mathrm{P}<0.05$, ${ }^{\star \star} \mathrm{P}<0.01$ and ${ }^{* \star *} \mathrm{P}<0.001$, versus control (multiple comparisons by Bonferroni test). Intergroup differences were significant $(\mathrm{P}<0.05-0.001)$ except for MNNCE\% (One-way ANOVA). ND= not done.

\section{Table 2}

\section{Peripheral blood micronucleus test in ribavirin-treated mice}

\begin{tabular}{|c|c|c|c|c|c|}
\hline Drug (mg/kg) & Sample time (h) & MNPCE\% & MNNCE\% & PCE\% & $P / N$ \\
\hline & 0 & $0.14 \pm 0.02$ & $0.09 \pm 0.01$ & $1.51 \pm 0.32$ & $0.01 \pm 0.00$ \\
\hline \multirow[t]{4}{*}{20} & 24 & $0.27 \pm 0.04^{\star \star}$ & $0.10 \pm 0.01$ & $1.57 \pm 0.14$ & $0.01 \pm 0.00$ \\
\hline & 48 & $0.28 \pm 0.05^{\star \star}$ & $0.17 \pm 0.02^{\star \star}$ & $1.59 \pm 0.11$ & $0.02 \pm 0.00$ \\
\hline & 72 & $0.18 \pm 0.05$ & $0.11 \pm 0.01$ & $1.27 \pm 0.06$ & $0.01 \pm 0.00$ \\
\hline & 0 & $0.20 \pm 0.04$ & $0.11 \pm 0.01$ & $1.94 \pm 0.15$ & $0.02 \pm 0.00$ \\
\hline \multirow[t]{2}{*}{100} & 24 & $0.23 \pm 0.04$ & $0.12 \pm 0.02$ & $1.22 \pm 0.10^{\star \star *}$ & $0.01 \pm 0.00^{* * *}$ \\
\hline & 0 & $016 \pm 0.04$ & $0.15 \pm 0.02$ & $2.73 \pm 1.09$ & $0.03 \pm 0.01$ \\
\hline \multirow[t]{3}{*}{200} & 24 & $0.18 \pm 0.05$ & $0.15 \pm 0.04$ & $2.39 \pm 1.19$ & $0.02 \pm 0.01$ \\
\hline & 48 & $0.65 \pm 1.15^{\star \star \star}$ & $0.12 \pm 0.02$ & $0.93 \pm 0.46^{\star *}$ & $0.01 \pm 0.01^{* *}$ \\
\hline & 72 & $0.80 \pm 0.55^{\star \star *}$ & $0.18 \pm 0.07$ & $1.77 \pm 1.02^{*}$ & $0.02 \pm 1.02^{*}$ \\
\hline
\end{tabular}

Values are mean \pm SEM from 5 animals/group. ${ }^{*} \mathrm{P}<0.05$, ${ }^{\star \star} \mathrm{P}<0.01$ and ${ }^{\star \star \star \star} \mathrm{P}<0.001$, versus respective control (multiple comparisons by Bonferroni test). Inter-group differences were significant for MNPCE\% $(\mathrm{P}<0.05-0.001)$; for MNNCE\% at $48 \mathrm{~h}(\mathrm{P}<0.01)$ in $20 \mathrm{mg} / \mathrm{kg}$, and at $48 \mathrm{~h}$ and $72 \mathrm{~h}$ in $100 \mathrm{mg} / \mathrm{kg}(\mathrm{P}<0.01)$. For $\mathrm{PCE} \%$ and $\mathrm{P} / \mathrm{N}$, at $48 \mathrm{~h}$ in 20 $\mathrm{mg} / \mathrm{kg}$, at $48 \mathrm{~h}$ and $72 \mathrm{~h}$ in $100 \mathrm{mg} / \mathrm{kg}(\mathrm{P}<0.001)$, and in all groups in $200 \mathrm{mg} / \mathrm{kg}(\mathrm{P}<0.01)$ (One-way ANOVA) 
Figure 2. Photomicrograph showing metaphase chromosome preparation from bone marrow. a) Chromatid break (arrow), b) chromosome break (arrow), c) ring chromosome (arrow), d) exchanges (arrows), e) deletion (arrow), f) minute (arrow), g) multiple breaks, h) pulverization, and i) fragmentation. Giemsa stain, 1000X.
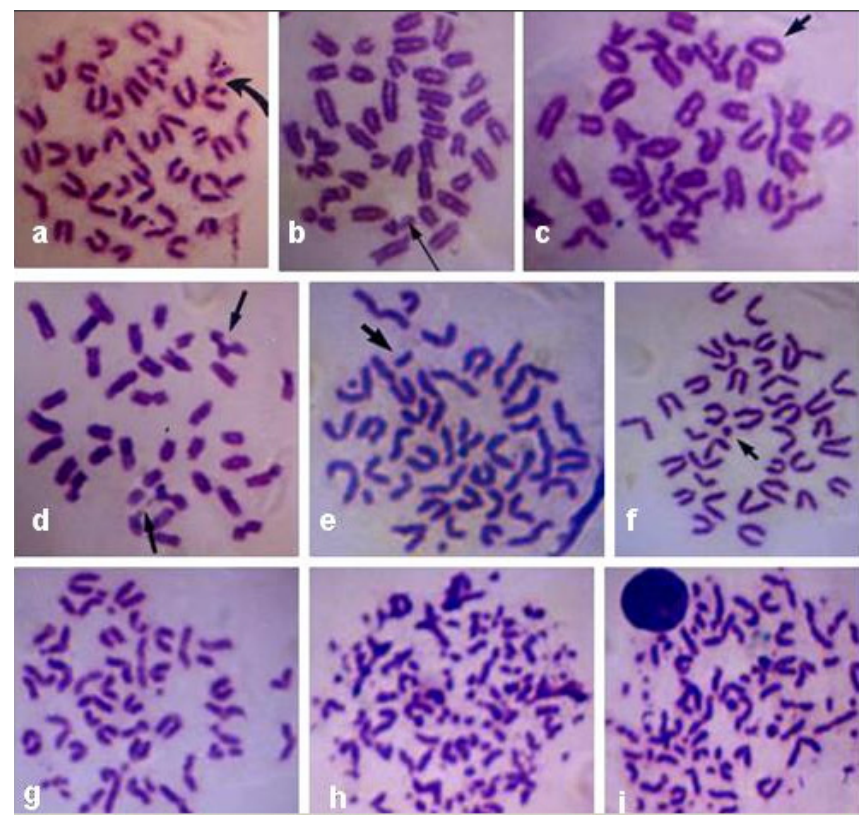

Table 3

Bone marrow mitotic chromosome test in ribavirin-treated mice

\begin{tabular}{ccccc}
\hline $\begin{array}{c}\text { Drug } \\
(\mathbf{m g} / \mathbf{k g})\end{array}$ & $\begin{array}{c}\text { Sample } \\
\text { time }(\boldsymbol{h})\end{array}$ & Total cells & $\mathbf{1}$ & $\mathbf{2}$ \\
\hline 0 & 24 & 300 & $0.67 \pm 0.54$ & 0 \\
& 48 & 300 & $18.33 \pm 2.84^{\star *}$ & $16.33 \pm 2.84^{\star *}$ \\
20 & 72 & 300 & $7.00 \pm 0.82^{\star}$ & $6.67 \pm 0.98^{*}$ \\
& 48 & 600 & $8.50 \pm 1.22^{\star}$ & $7.17 \pm 1.30^{*}$ \\
100 & 72 & 600 & $7.67 \pm 1.02^{\star}$ & $6.67 \pm 0.65^{*}$ \\
& 24 & 300 & $9.00 \pm 1.70^{\star *}$ & $6.67 \pm 0.98^{*}$ \\
200 & 48 & 300 & $11.33 \pm 2.37^{\star *}$ & $10.00 \pm 1.89^{*}$ \\
& 72 & 300 & $8.67 \pm 1.09^{*}$ & $6.67 \pm 1.19^{*}$ \\
\hline
\end{tabular}

Values are mean \pm SEM from 5 animals/group. $1=$ including cells with gaps, and $2=$ excluding cells with gaps. ${ }^{*} P<0.01$ and ${ }^{* *} P<0.001$, control versus treated (Bonferroni test). Intergroup differences are significant for $20 \mathrm{mg} / \mathrm{kg}$ at both sample times and for $200 \mathrm{mg} / \mathrm{kg}$ at $48 \mathrm{~h}(\mathrm{P}<0.01-0.001$; One-way ANOVA).

\section{Table 4}

Mitotic index in ribavirin-treated mice

\begin{tabular}{cccc}
\hline $\begin{array}{c}\text { Drug } \\
(\boldsymbol{m} \boldsymbol{g} / \mathbf{k g})\end{array}$ & $\mathbf{2 4} \boldsymbol{h}$ & $\mathbf{4 8} \boldsymbol{h}$ & $\mathbf{7 2} \boldsymbol{h}$ \\
\hline 0 & $6.38 \pm 0.33$ & $\mathrm{ND}$ & $\mathrm{ND}$ \\
20 & $1.90 \pm 0.20^{*}$ & $2.02 \pm 0.07^{\star}$ & $\mathrm{ND}$ \\
100 & $1.53 \pm 0.16^{\star}$ & $2.12 \pm 0.10^{*}$ & $\mathrm{ND}$ \\
200 & $2.27 \pm 0.03^{\star}$ & $2.15 \pm 0.65^{\star}$ & $3.22 \pm 0.57^{\star}$ \\
\hline
\end{tabular}

Values are represented as mean \pm SEM from 5 animals/group. ${ }^{*} \mathrm{P}<0.01$ against control (Bonferroni test). ND= not done. The $24 \mathrm{~h}$ values served as control for 48 $\mathrm{h}$ and $72 \mathrm{~h}$ groups.
Figure 3. Photomicrograph showing different sperm abnormalities. a) Normal sperm, b) hook-less, c) amorphous, d) bananashaped, e) folded, and f) two-tailed sperms. Eosin Y, 1000X.
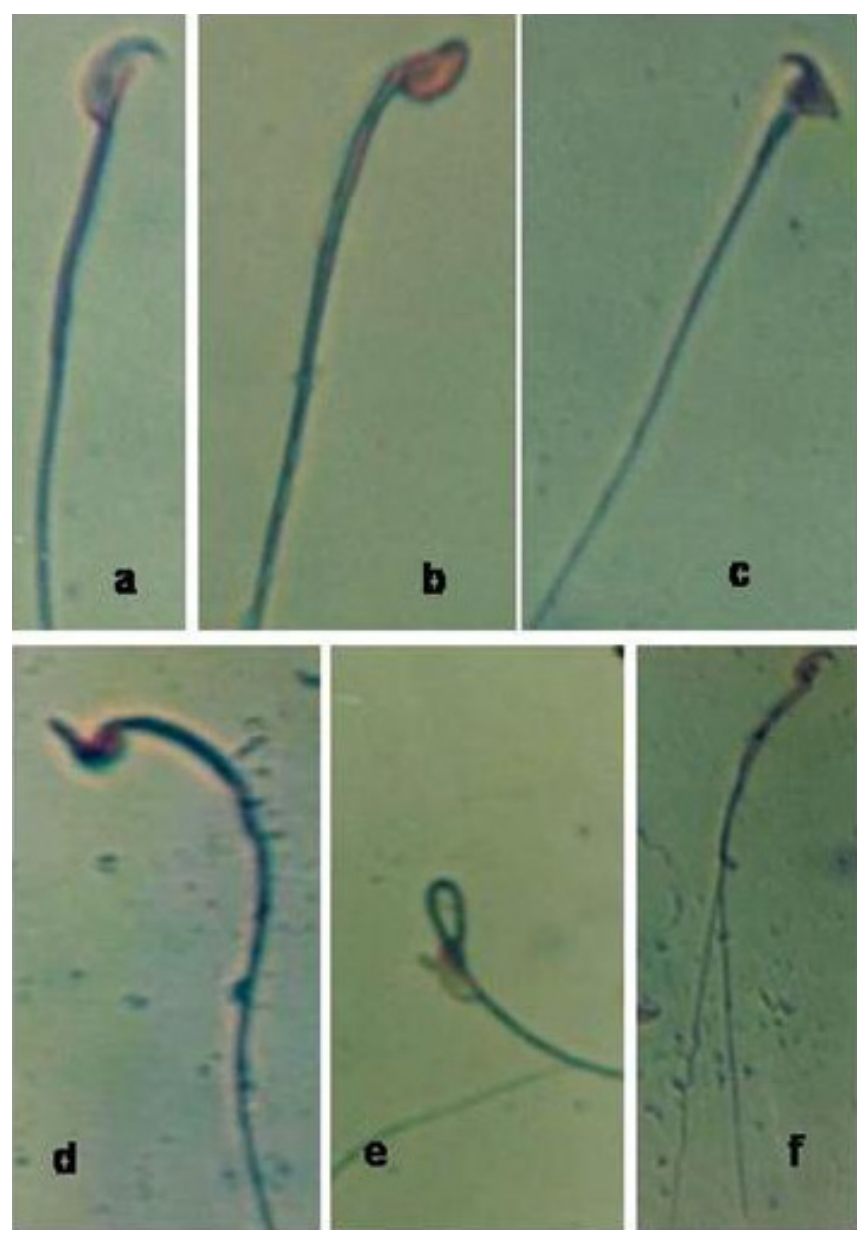

Bone marrow mitotic chromosome analysis

Ribavirin induced the formation of cells with structurally damaged chromosomes (Figure 2). Chromatid gaps and breaks, chromosome breaks, deletions and exchange figures were the most common structural damages. There was no dosedependent increase in chromosomal damage and the effects of $20 \mathrm{mg} / \mathrm{kg}$ were more at $24 \mathrm{~h}$ (Table 3). All doses of ribavirin decreased the mitotic index, but without any particular relation to the doses or time points employed (Table 4).

\section{Sperm morphology assay}

Ribavirin decreased the testes weight (control 257.28 \pm 11.54 and treated- 200.00+10.90, $\mathrm{P}<0.01$ ) and increased the number of sperms with abnormal morphology (control$1.59+0.26$ and treated-9.14+1.16, $\mathrm{P}<0.001$ ) (Figure 3).

\section{Discussion}

The bone marrow micronucleus test has been a most suitable genotoxicity test ${ }^{[24]}$ along with simultaneously used tests like chromosome aberration, peripheral blood micronucleus and sperm morphology tests. This battery of tests would ensure a $100 \%$ accurate genotoxicity testing. ${ }^{\mid 25]}$ 
Previous studies on genotoxicity of ribavirin have employed any one of these tests except a study by Rao and Rahiman ${ }^{[12]}$ which also included chromosome aberration test, but following multiple treatments with $200 \mathrm{mg} / \mathrm{kg}$, and another study by Phillips et al ${ }^{[13]}$ who also conducted the peripheral blood micronucleus test after multiple exposures to very high doses. The doses of $500-2000 \mathrm{mg} / \mathrm{kg}$ used in the latter study ${ }^{[13]}$ were so high so that they might have been highly toxic and arrested cell proliferation, and consequently micronucleus formation. However, they were able to observe the micronucleated cells in the venous blood.

A significant increase in MNPCE\% indicated that ribavirin induced chromosomal damage in mouse bone marrow cells. In mice exposed to two treatments of $200 \mathrm{mg} / \mathrm{kg}^{[12]}$ or three treatments of $500-2000 \mathrm{mg} / \mathrm{kg},{ }^{[13]}$ the frequency of micronuclei did not show any dose-dependent responses. The results indicated that dose-response was not well defined as regards the MNPCE\% in mice, except at $72 \mathrm{~h}$ (Table 1). The study by Phillips et al ${ }^{[13]}$ did not however examine the incidences of micronuclei at that sample time. On the other hand, dosedependent increase in MNPCE\% was observed in Wistar rats following a single treatment of $10-200 \mathrm{mg} / \mathrm{kg}$; at $10 \mathrm{mg} / \mathrm{kg}$ the drug did not induce any mutagenicity and it was concluded that the $10 \mathrm{mg} / \mathrm{kg}$ was a 'no observed adverse effect doselevel $^{[17]}$. In that study even the MNNCEs significantly increased due to conversion of the MNPCEs by $24 \mathrm{~h}$ itself, however, no such effect was observed in the present study. This was due to the higher degree of variations among the animals. Why do these differences exist between different species? It is known that the metabolites - ribavirin 5' monophosphate (RMP) and ribavirin 5' triphosphate (RTP) are more toxic than the parent compound. ${ }^{|2|}$ The availability of these metabolites to the target tissue (in this case, the bone marrow) therefore would depend on the extent of metabolism of ribavirin in the liver which might vary from species to species. Only at $200 \mathrm{mg} / \mathrm{kg}$, the MNPCEs were less in number at $48 \mathrm{~h}$ than the other 2 samples and that was due to increased toxicity of higher dose, which did not allow the cells to enter into mitosis. This quality of the drug was not observed in the rat following a single treatment and there was an increase in MNPCE\% at $48 \mathrm{~h}$ compared to 2 other samples. ${ }^{[1]}$ Thus, the present study differs from that of Narayana $e t$ al, ${ }^{[17]}$ and the differences are probably due to, 1) lack of well-defined dose-response, 2) time-response, and 3) negligible number of MNNCEs in the mouse bone marrow.

The results from the peripheral blood micronucleus test further indicated that the responses of MNPCEs were totally different from that of the bone marrow. In contrast to the bone marrow, the MNPCEs were more at $48 \mathrm{~h}$, and by $72 \mathrm{~h}$ they decreased except in $200 \mathrm{mg} / \mathrm{kg}$. Relatively more MNPCEs observed at $24 \mathrm{~h}$ in the bone marrow reached the blood by $48 \mathrm{~h}$, which may be responsible for such an observation in the blood. Increased incidence of micronucleated cells at $72 \mathrm{~h}$ in the 200 $\mathrm{mg} / \mathrm{kg}$ group was an aftermath of extended toxicity of this higher dose, which kept on generating the micronuclei in the bone marrow and consequently in the blood. Lack of dosedependent increase of MNPCEs at $24 \mathrm{~h}$ was probably due to the drug toxicity, which prevented the cells from leaving the bone marrow to reach the blood by $24 \mathrm{~h}$, which otherwise would have reached approximately at that time. ${ }^{[26]}$ Compared to the study of Phillips et al ${ }^{[12]}$ the MNPCEs were more in this case. Since the doses employed here were comparatively lower, that probably exerted less cytotoxicity providing more dividing cells in the marrow to be acted upon.

Following the exposure to ribavirin, structural damage took place in affected cells that resulted in the formation of acentrics (chromosome fragments). When the enucleation of erythrocytes occurs, the acentrics are not extruded from the cells; instead they appear as small bodies called micronuclei. The whole chromosome left in the cell due to non-disjunction could also form the micronuclei, but in that case the latter would be larger in size. Thus, the small-sized micronuclei which appeared in the cells in the present study indicate that they are formed by the acentrics and that this finding is in consensus with the type of chromosomal damage observed. However, the formation of acentrics did not show any dose-dependent response. Thus formed acentrics transformed into micronuclei by $24 \mathrm{~h}$ resulting in a significant increase in their number in the bone marrow by that time (Table 1). Inhibition of inosine monophosphate dehydrogenase would result in decreased xanthosine monophosphate formation required for DNA synthesis, ${ }^{[27]}$ and ribavirin 5' triphosphate also could inhibit RNA polymerase by competing with GTP or ATP for substrate sites. ${ }^{[28]}$ These actions of the drug therefore could affect the DNA structure leading to chromosomal damage in cells. Primarily, ribavirin induced the chromatid type of aberration (chromosome type was also seen at higher dose levels), which indicated that the drug possibly acted on cell-cycle stages late $\mathrm{S}$ and $\mathrm{G}_{2}$ similar to other drugs like Ara $\mathrm{C}$ and 5-Fluorouracil. ${ }^{[29]}$ Compared to the total chromosome damage that led to the formation of acentric fragments, the frequencies of micronuclei were less in the bone marrow and consequently in the blood. This might account for the fact that all acentrics are not converted into micronuclei, ${ }^{[26]}$ or not all of them are observed under the light microscope. ${ }^{[25]}$

Evaluation of mitotic index (MI) revealed that ribavirin affected the cell division adversely in the bone marrow supporting the previous findings on cytotoxicity that induced the cell death in rat bone marrow and testis. ${ }^{[30]}$ The decrease in testis weight was due to decreased spermatogenesis owing to the drug-induced cytotoxicity. ${ }^{[23]}$ In previous studies, this drug was found to induce the formation of abnormal sperms and decrease the sperm count in the rat. ${ }^{[15,16]}$ Nevertheless, in this study hook-less sperms were more and also the percentage abnormality at $200 \mathrm{mg} / \mathrm{kg}$ was less than that in the rat. Sperm abnormalities are induced by exogenous compounds via point mutations ${ }^{[15]}$ or due to the inimical nature of chemicals on spermato-genesis. ${ }^{[23]}$

In conclusion, the results of this study infer that ribavirin is a potent mutagen that causes structural damages in chromosomes and acts as a cytotoxic agent in mice. Further, it also induces point mutations in the germ cells thus inducing the formation of abnormal sperms. The genotoxicity of this drug is not exerted in a dose-dependent pattern.

\section{References}

1. Parfitt K. Martindale: The complete drug reference. $32^{\text {nd }}$ ed. MA: Pharmaceutical Press; 1999.

2. Lauglin CA, Tseng CK. Antiviral agents, RNA viruses other than HIV. In: Wolf $M E$,editor. Bergers' Medicinal Chemistry and drug discovery. New York: Wiley; 
1997.

3. American Medical Association (AMA). Drug evaluations. Messachsetes: Antiviral agents; 1993.

4. Canonico PG, Kastello MD, Cosgriff TM, Donovan JC, Ross PE, Spears CT, et al. Haematological and bone marrow effects of ribavirin in rhesus monkeys. Toxicol Appl Pharmacol 1984;74:163-72.

5. Canonico PG, Kastello MD, Spears CT, Brown JR, Jackson EA, Jenkins DE. Effect of ribavirin on red blood cells. Toxicol Appl Pharmacol 1984;74:155-62.

6. Cosgriff TM, Hodgson LA, Canonico PG, White JD, Kastello MD, Donovan JC, et al. Morphological alterations in blood and bone marrow of ribavirin-treated monkeys. Acta Haematol 1984;72:195-200.

7. Ferm VH, Willhite C, Kilham L. Teratogenic effects of ribavirin on hamster and rat embryos. Teratology 1978;17:93-101.

8. Kilham L, Ferm VH. Congenital anomalies induced in hamster embryos with ribavirin. Science 1977;195:413-4.

9. Kochhar DM, Penner JD, Knudsen TB. Embryotoxic, teratogenic and metabolic effects of ribavirin in mice. Toxicol Appl Pharmacol 1980;52:99-112.

10. Maugh TH. Chemotherapy: Antiviral agents come of age. Science 1976; 194:128-32.

11. Arky R. Physicians' desk reference. Siflon DW, editor. Montvale NJ: Medical Economics Company; 1996.

12. Rao KP, Rahiman MA. Cytogenic effects of ribavirin on mouse bone marrow. Mutat Res 1989;224:213-8.

13. Phillips MD, Nascimbeni B, Tice RR, Shelby MD. Induction of micronuclei in mouse bone marrow cells: An evaluation of nucleoside analogues used in the treatment of AIDS. Environ Mol Mutagen 1991;18:168-83.

14. Hoffman SH, Wade MJ, Staffa JA, McGregor DB, Holmstrom M, Dayan AD. Dominant lethal study of ribavirin in male rats. Mutat Res 1987;188:29-34.

15. Narayana K, D'Souza UJ, Rao KP. Ribavirin-induced sperm shape abnormalities in Wistar rat. Mutat Res 2002;513:193-6.

16. Narayana K, D'Souza UJ, Rao KP. Effect of ribavirin on epididymal sperm count in rat. Indian J Physiol Pharmacol 2002;46:97-101.

17. Narayana K, D'Souza UJ, Rao KP. The genotoxic and cytotoxic effects of ribavirin in rat bone marrow. Mutat Res 2002;521:179-85

18. Joksic G, Stankovic M, Vasic V, Cakar M, Jokanovic M. Influence of Ribavirin on the micronucleus formation and in vitro proliferation of human lymphocytes. Neoplasma 2000;47:283-7.

19. Narayana K, D'Souza UJ, Rao KP. Possible reasons for spontaneous incidence of micronucleus in rodents. Indian J Physiol Pharmacol 1999;43:515-7.

20. Adler ID. Cytogenetic tests in mammals. In: Venitt S, Parry JM, editors. Mutagenicity testing: A practical approach. Oxford: IRL Press; 1984.

21. Savage JR. Classification and relationships of induced chromosomal structural changes. J Med Genet 1975;12:103-22.

22. Wyrobek AJ, Bruce WR. Chemical induction of sperm abnormalities in mice. Proc Natl Acad Sci USA 1975;72:4425-9.

23. Wyrobek AJ, Gordon LA, Burkhart JG, Francs MW, Kapp RW Jr , Letz G, et al. An evaluation of the mouse sperm morphology test and other sperm tests in non-human mammals. Mutat Res 1983;115:1-72.

24. Hayashi M, Tice RR, MacGregor JT, Anderson D, Blakey DH, Kirsch-Volders M, et al. In vivo rodent erythrocyte micronucleus assay. Mutat Res 1994;312: 293-304.

25. Muller WU, Strffer C. Micronucleus assay. In: Obe G, editor. Advances in Mutagenesis Research-5. New York: Springer; 1994.

26. MacGregor JT, Wehr CM, Gould DH. Clastogen-induced micronuclei in peripheral blood erythrocytes: The basis of an improved micronucleus test. Environ Mutagen 1980;2:509-14.

27. Wray SK, Gilbert BE, Noall MW, Knight V. Mode of action of ribavirin: Effect of nucleotide pool alterations on influenza virus ribonucleoprotein synthesis. Antiviral Res 1985;5:29-37.

28. Goswami BB, Borek E, Sharma OK, Fujitaki J, Smith RA. The broad-spectrum antiviral agent ribavirin inhibits capping of $m-R N A$. Biochem Biophys Res Commun 1979;89:830-6.

29. Bender MA, Griggs HG, Bedford JS. Mechanisms of chromosomal aberration production: III. Chemicals and ionizing radiation. Mutat Res 1974;23:197-212.

30. D'Souza UJ, Narayana K. Mechanism of cytotoxicity of ribavirin in the rat bone marrow and testis. Indian J Physiol Pharmacol 2002;46:468-74.

\title{
PHARMA CME - 2005
}

Date

Place

Theme

Workshop : Non-invasive Techniques in Clinical Pharmacology

: July $9^{\text {th }}-10^{\text {th }}, 2005$

: Rangaraya Medical College, Kakinada, Andhra Pradesh

: Modern Trends in Pharmacotherapeutics

\section{For further information please contact:}

\author{
Organizing Secretary, \\ Department of Pharmacology, \\ Rangaraya Medical College, \\ Kakinada. Andhra Pradesh. \\ Ph: - $0884-2344836$
}

E-Mail : rmcpharma_2005@ hot mail.com 